\title{
Impact of beach replenishment on the fauna of a sandy beach at the Dutch islands of Texel and Ameland
}

Norbert Dankers, Michel Binsbergen and Koos Zegers (Research Institute for Nature Management (RIN), Texel Branch, P.O. Box 59, 1790 AB Den Burg, Netherlands)

Accepted: 1 June 1984

\begin{abstract}
Along the Dutch coast, erosion is locally strong and is combated by building breakwaters and groynes and, more recently, by replenishment with new sand. In Texel and Ameland, different methods were used. In Texel, almost all benthic macrofauna died whereas, in Ameland, most benthic animals survived. This was clearly shown by the fact that in Texel the numbers of sanderling (Calidris alba) decreased drastically.
\end{abstract}

Key-words: sandy beach, erosion, macrobenthos, beach replenishment, beach nourishment.

Introduction. In coastal defence, beach replenishment is increasingly used in the Netherlands. During regular investigations, it was observed that almost all birds disappeared from the newly formed beach. The beach replenishments of Texel in 1979 and Ameland in 1980 were used to study the effects on the macrofauna and the recovery period.

Beach replenishment. On the beach of Texel a layer of sand 1.5-4.0 m thick was deposited over an average width of $500 \mathrm{~m}$ from well above the high-tide mark to well below the low-water mark in August to November 1979. In Ameland, however, the sand was deposited above the high-tide mark to a thickness of $7 \mathrm{~m}$, and later storms spread the sand over the beach. The work in Ameland was carried out in October and November 1980.

Methods. On the beaches, samples were taken in the replenished beach as well as in an undisturbed part. The beach was subdivided into three parts: a high beach from $+30 \mathrm{~cm}$ up to $+100 \mathrm{~cm}$ with reference to mean tide level, a middle beach from +30 $\mathrm{cm}$ to $-30 \mathrm{~cm}$ and a low beach from $-30 \mathrm{~cm}$ to $-100 \mathrm{~cm}$. Samples of each beach section were analysed separately. All samples were sieved over a 1-mm mesh, and all animals were counted, dried at $60^{\circ} \mathrm{C}$, weighed, ashed, and weighed again.

Results. Few species of macrobenthic fauna occurred on the beach, but the polychaete Scolelepis squamata occurred at high densities (up to $40 \mathrm{~g} \mathrm{~m}^{-2}$ ash-free dry weight). In Fig. 1, the results are summarized. On the Texel beach, almost all adults disappeared, whereas no effect of the works could be detected on the Ame- 
TEXEL

untreated replenished

HIGH BEACH

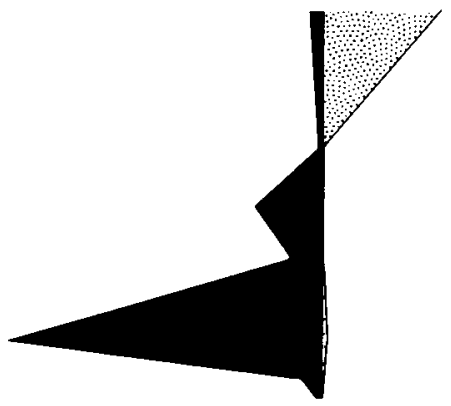

MIDDLE BEACH

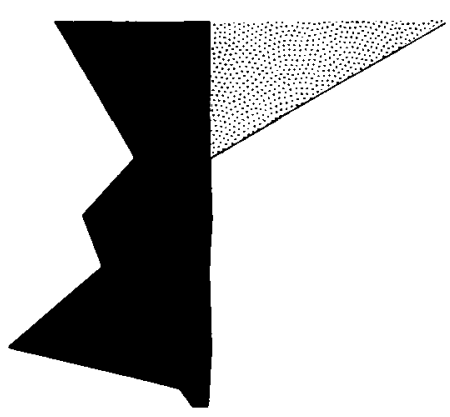

LOW BEACH

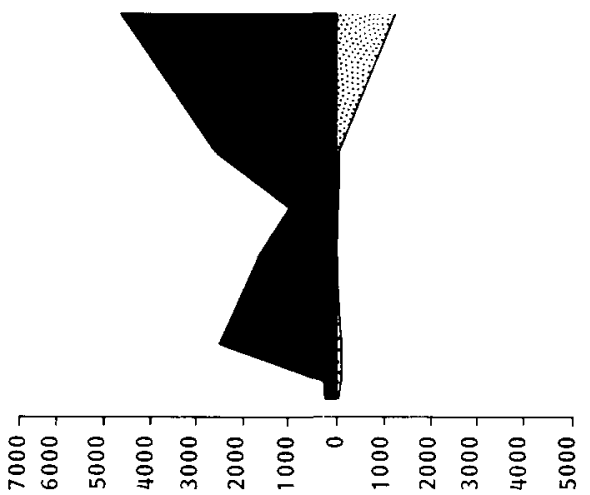

Numbers $\mathrm{m}^{-2}$
AMELAND

untreated replenished

HIGH BEACH

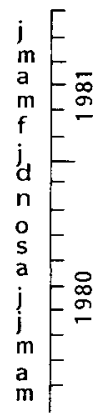

MIDDLE BEACH

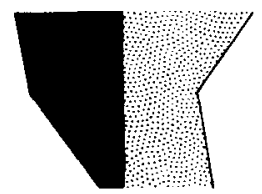

LOW BEACH
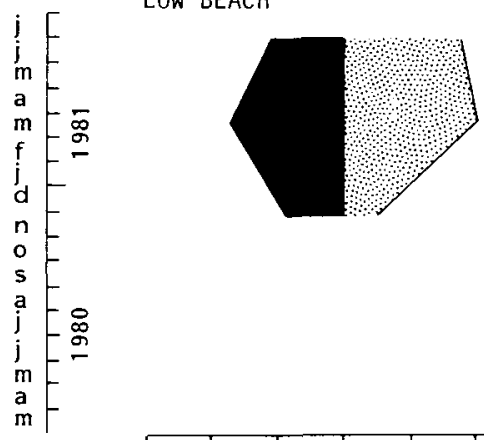

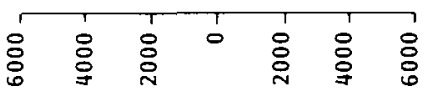

Numbers $\mathrm{m}^{-2}$

Fig. 1. The development of numbers of adult worms (Scolelepis squamata) on the untreated and replenished beaches of the islands of Texel and Ameland during several months after the replenishment. 
land beach. In summer 1981, almost two years after the replenishment commenced, the densities on the Texel beach were back to normal. Juvenile organisms reappeared in autumn 1980.

Conclusions. Depending on the way the works are performed, the benthic fauna can be almost completely destroyed. However it is not a rare fauna and recovery is almost complete after some years. Locally, predators will find less food and will have to move further along the beach.

In relation to the beneficial effects such as the preservation of a natural coastline, and the conservation of rare and valuable dune vegetation, beach replenishment can be considered a recommendable method if the sand is extracted from a suitable place.

This synopsis is based on a report entitled 'De effecten van zandsuppletie op de fauna van het strand van Texel en Ameland', Research Institute for Nature Management, 1983. ii +12 pp., 5 figs., 1 table, 9 refs. Dutch.

Available as paper copy (order R012P, $f 3.70$ including postage) or microfiche (order R012 M, f 12.50 including postage) at: NARD, clo Pudoc, P.O. Box 4, 6700 AA Wageningen, Netherlands (telex $45015 \mathrm{blhwg} \mathrm{hl}$ ).

\section{Development and growth of trees in small-scale regeneration}

L. J. G. Koks and R. P. Leersnijder (Department of Silviculture, Agricultural University, P.O Box 342, $6700 \mathrm{AH}$ Wageningen, Netherlands)

Accepted: 5 June 1984

Abstract. A graphical and mathematical model was developed to describe natural or artificial regeneration of trees in systems of small-scale silviculture. The pattern of growth was particularly influenced by light conditions and by root competition at the edges of the clearing.

Key-words: growth rate; small-scale regeneration; root competition; competition; small-scale forest management; graphical model.

Introduction. Small-scale forest management is defined as management in a system with regeneration units under a canopy gap which has a diameter of not more than three times the tree height. The microclimate so remains the predominant factor. The aim of management is wood production and maintenance of the forest as a 